\title{
THE ROLE OF CLOUD TECHNOLOGIES IN THE DIGITAL ECONOMY
}

\author{
${ }^{\odot 2020}$ DAVYDOV D. S., RIABOVOL D. A., KRAMARENKO A. 0., KVITKA A. V.
}

UDC 338.47

JEL: C88; L86

\section{Davydov D. S., Riabovol D. A., Kramarenko A. O., Kvitka A. V. The Role of Cloud Technologies in the Digital Economy}

At the present stage of the development of the digital economy especially relevant are the technologies that are universal in nature and will be able to change the business processes of modern Internet companies. One of such directions is cloud solutions that allow, among other things, faster access to the necessary information, minimizing the locally occupied memory, by shifting basic information operations to remote capacities, while accelerating many processes and making the expensive infrastructure unnecessary. However, it is worth noting the existence of a number of restrictions related to insufficient awareness of companies as to new solutions, as well as their link to existing solutions, which makes it quite difficult for them to fulfill transition to new, more efficient cloudbased instruments. The authors analyze the key factors of both positive and negative nature, which in some way or another influence the decision-making by digital companies on the beginning of active application of this complex of new technologies. A substantiation for the feasibility of such innovations is provided. The main trends of digital economy development and the process of digitalization with integration of traditional industries therein are considered. The main advantages and contradictions of implementation of the cloud technologies on a wide basis are shown. The relationship between the growth of quantity of information in the digital economy and the need to create effective mechanisms for processing and storing it based on the Public Cloud technologies is specified. The peculiarities of the API-first business model of companies that are actively developing in the face of growing global volume of information are considered. Examples of the positive effect of using cloud computing technologies in the digital product creation are presented and the industry's major players are listed. The importance of government initiatives for implementing innovations is noted. Actual directions of increasing the potential of using cloud technologies in business are identified.

Keywords: digital economy, cloud technologies, cloud computing, digitalization, Big Data.

DOl: https://doi.org/10.32983/2222-4459-2020-8-171-177

Fig.: 2. Bibl.: 20.

Davydov Denys S. - PhD (Economics), Associate Professor, Associate Professor of the Department of Management and Administration, Educational and Research Institute "Karazin Business School» of V. N. Karazin Kharkiv National University (1 Myronosytska Str., Kharkiv, 61002, Ukraine)

E-mail:d.davydov@karazin.ua

ORCID: http://orcid.org/0000-0002-8323-1597

Riabovol Dmytro A. - Student of the Faculty of Economics, V. N. Karazin Kharkiv National University (4 Svobody Square, Kharkiv, 61022, Ukraine)

E-mail: dimaruabovol@gmail.com

ORCID: $h$ ttp://orcid.org/0000-0002-6054-5155

Kramarenko Anna 0. - PhD (Economics), Senior Lecturer of the Department of Management and Administration, Educational and Research Institute "Karazin Business School» of V. N. Karazin Kharkiv National University (1 Myronosytska Str., Kharkiv, 61002, Ukraine)

E-mail: a.o.kramarenko@karazin.ua

ORCID: http://orcid.org/0000-0001-5987-1247

Kvitka Anton V. - PhD (Economics), Associate Professor, Deputy Director of the Educational and Research Institute "Karazin Business School» of V. N. Karazin Kharkiv National University (1 Myronosytska Str., Kharkiv, 61002, Ukraine)

E-mail: kvitka@karazin.ua

ORCID: http://orcid.org/0000-0002-5730-1352

УДК 338.47

JEL: C88; L86

Давидов Д. С., Рябовол Д. А., Крамаренко А. О., Квітка А. В. Роль хмарних технологій у цифровій економіці

На даному етапі розвитку цифрової економіки особливо актуальними стають технології, які мають універсальний характер і здатні змінити бізнес-процеси сучасних Інтернет-компаній. Одним із таких напрямків є хмарні рішення, що дозволяють, серед іншого, швидше отримувати доступ до необхідної інформації, мінімізувати займані локально обсяги пам'яті, перенісши основні інформаційні операції на віддалені потужності, при иьому прискорюючи багато процесів і роблячи непотрібною дорогу інфраструктуру. Проте варто відзначити наявність ряду обмежень, пов'язаних з недостатньою поінформованістю компаній про нові рішення, а також іх прив'язкою до вже існуючих рішень, що робить для них доволі складним перехід до нових, більш ефективних інструментів на основі хмарних технологій. Проведено аналіз ключових факторів як позитивного, так і негативного характеру, які тією чи іншою мірою впливають на прийняття цифровими компаніями рішень про початок активного застосування цього комплексу нових технологій. Дано обгрунтування доцільності таких інновацій. Розглянуто основні тренди розвитку цисррової економіки та процесу диджиталізації-інтеграції в неї традиційних галузей. Показані основні переваги та суперечності впровадження на широкій основі хмарних технологій. Позначено взаємозв'язок між зростанням кількості інформації в цифровій економіиі та необхідністю створення ефективних механізмів ії обробки та зберігання на основі технологій Public Cloud. Розглянуто особливості бізнес-моделі API-first компаній, які активно розвиваються в умовах зростаючого глобального обсягу інформаиії. Наведено приклади позитивного ефекту від використання технологій хмарних обчислень в умовах створення цифрового продукту, а також перераховано основних гравиів галузі. Позначено важливість державних ініціатив для впровадження інновацій. Виявлено актуальні напрямки підвищення потенціалу використання хмарних технологій у бізнесі. Ключові слова: цифрова економіка, хмарні технології, хмарні обчислення, диджиталізація, Big Data.

Рис.: 2. Бібл.: 20.

Давидов Денис Станіславович - кандидат економічних наук, доцент, доцент кафедри управління та адміністрування, Навчально-науковий інститут «Каразінська школа бізнесу» Харківського національного університету імені В. Н. Каразіна (вул. Мироносицька, 1, Харків, 61002, Україна) E-mail:d.davydov@karazin.ua

ORCID: $h$ ttp://orcid.org/0000-0002-8323-1597 
Рябовол Дмитро Анатолійович - студент економічного факультету, Харківський національний університет ім. В. Н. Каразіна (пл. Свободи, 4, Харків, 61022, Україна)

E-mail: dimaruabovol@gmail.com

ORCID: http://orcid.org/0000-0002-6054-5155

Крамаренко Анна Олександрівна - кандидат економічних наук, старший викладач кафедри управління та адміністрування, Навчально-науковий інститут «Каразінська школа бізнесу» Харківського національного університету імені В. Н. Каразіна (вул. Мироносицька, 1, Харків, 61002, Україна) E-mail: a.o.kramarenko@karazin.ua

ORCID: http://orcid.org/0000-0001-5987-1247

Квітка Антон Володимирович - кандидат економічних наук, доцент, заступник директора Навчально-наукового інституту «Каразінська школа бізнесу» Харківського національного університету імені В. Н. Каразіна (вул. Мироносицька, 1, Харків, 61002, Україна)

E-mail: kvitka@karazin.ua

ORCID: http://orcid.org/0000-0002-5730-1352

I n today's digital economy, its key technologies are gaining ever-increasing global economic importance. The scale of the impact of this phenomenon can hardly be overestimated since the majority of the largest sectors of the world economy are already widely connected with the use of digital tools, mechanisms, and platforms. Trade, global economic relations between businesses and customers, cross-border payments - all this and much more today cannot be imagined without the availability of convenient and easy-to-use digital tools, online platforms and applications.

The problem of understanding the potential of cloud technologies as a significant part of this process (the study of which this paper is devoted) is highly relevant today since this sphere can bring significant benefits both in the form of savings on infrastructure and the introduction of more effective mechanisms for creating value in the digital economy. Studies from Eurostat, Deloitte, and Statista show that despite the rapid growth of the cloud computing industry, it can also face several barriers, such as lack of awareness, the cost of moving from traditional infrastructure, etc.

This paper highlights the main aspects regarding the role of cloud innovations, their impact on business processes (by creating new niches and tools) and user interaction with a digital product. The results can be useful for a wide range of researchers and entrepreneurs, as they form a holistic view of the actively emerging industry that shows a significant growth perspective.

Theoretical basis. This research contains information from the following sources: the Information Technology Association of Canada; Deloitte; Boston Consulting Group; Statista; Synergy Research Group; European Commission. The data received from these and other sources made it possible to create a holistic understanding of the dynamics of innovation in the sphere of cloud storage and data processing, to identify the most characteristic problems and limitations, as well as current challenges that need to be addressed. The main conclusions of the publication were made using the information from these research papers. This study provides a comprehensive analysis of the sphere of cloud technologies from an economic and an entrepreneurial point of view.
Along with the basic technologies of its initial formation (the Internet, personal computers, semiconductors), the digital economy is gaining new facets, involving in this process not only the sphere of virtual and online products that were previously impossible (search engines, messengers, video streaming services, social networks) but also a wide range of so-called digitalized industries. This may include such areas as the "sharing economy" (Uber, Airbnb), "gig economy" (Fiverr), and ecommerce (Amazon, eBay, Zappos).

Against this background, the most valuable resource of the digital economy is data, the volumes of forwarding and processing of which are steadily increasing year after year. In 2019 alone, the world created an additional 47 zettabytes of information (1 ZB = 1 billion terabytes), which is 534 million times more than the entire Internet in 1997 (88 terabytes) [1, p. 6-7]. If the current trend continues, then we will see more than 175 zettabytes of information created over 2025 [same source] (Fig. 1).

$\Lambda$ s one of the factors of such active growth, we can mention that a fully autonomous car (an innovation that is actively developing towards widespread adoption) will have to process over 100 terabytes of information from various sensors during the eighthour trip to make its driving decisions [2].

In conditions of a surplus of information, one of the most relevant technologies of the Fourth Industrial Revolution (based on the digital economy), is cloud solutions, which make it possible today to achieve significant savings in the implementation of both routine and innovative tasks. Cloud services are a response to everincreasing volumes of data, with billions of users and customers around the world. Today, over 5 billion people are already somehow represented in the digital space, and this figure may well increase to 6 billion $(75 \%$ of the world's population) by 2025 [3, p. 5].

In such conditions, we can see a significant decrease in the percentage of information stored on the devices, and the active transition to cloud storage solutions. This process is largely similar to the shift from desktop devices to mobile. What is also important to pay attention to is the fact that if in the early 2010 s $80-90 \%$ of the 


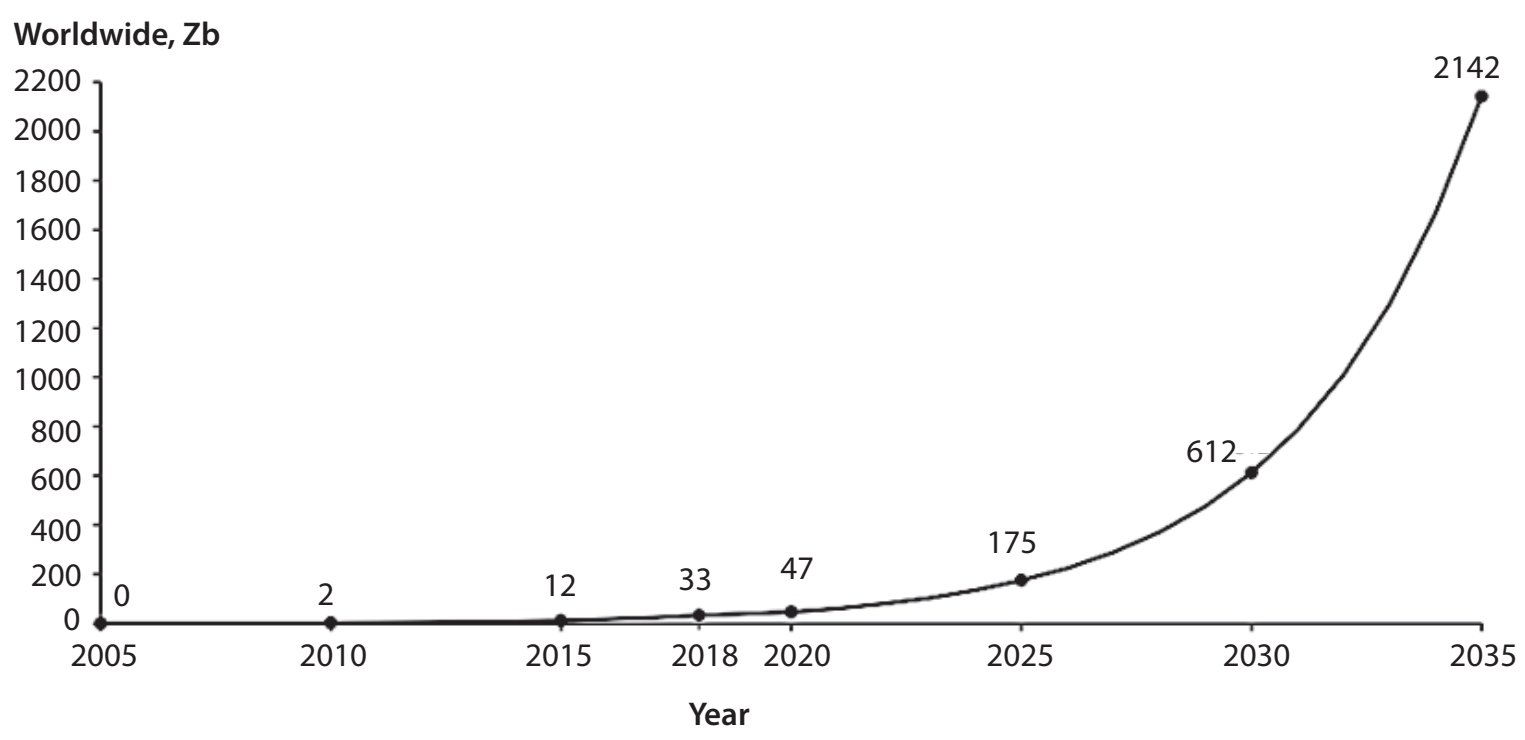

Fig. 1. Worldwide amount of data created per year in zettabytes [1]

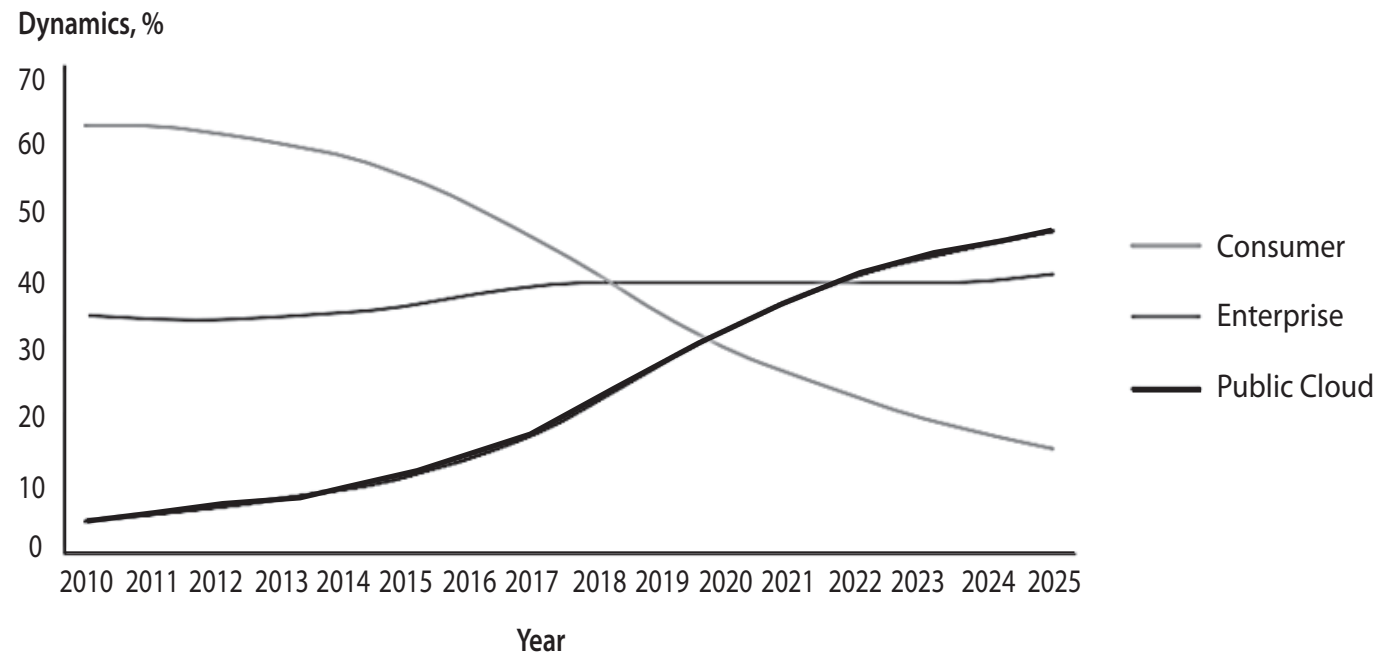

Fig. 2. The dynamics behind the cloud storage transformation [3]

information was stored in the framework of traditional data centers, then in 2020, this share is only about $50 \%$ [3, p. 11] (Fig. 2).

$\mathrm{U}$ sing cloud solutions can bring many advantages both at the individual user level and at the level of large leading companies. Here we can note the significant scalability of such solutions, as well as a high degree of flexibility that allows saving on excess capacity, the ability to process the received data for commercial purposes, economies of scale, and reliability. These improvements would not be possible when using the infrastructure owned by the company itself.

Earlier, before the stage of active distribution of cloud solutions among commercial customers began, many companies had to spend significant financial resources on building their infrastructure, as well as maintaining it by qualified operators. It was also a kind of cloud solution, allowing, for example, a team of 10 people to work together on a project, but it was a "private cloud" mechanism.

For example, in case of a sudden surge in the load on the company's server capacities (in case of unforeseen fluctuations in the demand for the product), in most cases, it was forced to make additional investments in infrastructure. We can also note that usually such infrastructural solutions should be located in separate rooms, and under controlled temperature conditions.

As for the current trend in the development of cloud innovations in the digital economy, it is worth talking about systems available to a large number of users public cloud solutions. However, it should be noted that we should not limit the study by describing the significance of only this technology. It is also possible to distinguish some specialized (adapted to the needs of a particular company) distributed (using a set of interconnected systems that often provide more stable and high-speed intercommunication for time-sensitive operations) and 
"multi-cloud" (combining the necessary functions of several providers) systems [4, p. 7].

Among the main players in this rapidly expanding market are the following: Google Cloud, Amazon Web Services, Oracle Cloud, Microsoft Azure, SAP Cloud Platform, etc. The volume of the cloud computing market, according to a study from Synergy Research Group for 2019 amounted to more than $\$ 130$ billion [5].

A $\mathrm{s}$ already mentioned, the benefits of open cloud solutions based on the principle of remote use of infrastructure are expressed primarily in the high level of their influence on the financial performance of a company. It is worth noting the low relative cost of such solutions in comparison with the available computer capacities and the amount of memory for storing data, not to mention the tools for processing large amounts of information or mechanisms for creating artificial intelligence elements.

The expenses of any company to maintain its IT infrastructure and processes, like all others, can be divided into two categories: capital and operating. As for the capital IT expenses, they can often be expressed in server capacities, power systems, air conditioning systems, backup power generators, etc. As a rule, their presence implies significant initial costs for the acquisition and installation. At the same time, operating costs, which also include cloud solutions, are often more efficient due to their flexibility and adaptability.

Thus, the transition in the provision of IT infrastructure from the capital to operating expenses will allow quick access to the latest technologies, while ensuring the ability to switch to other levels of productivity. It will be possible without loss in the form of suspension of the product (application, online service). There also will be no need for additional investments or updates, not to mention the high level of automation and autonomy of such solutions [4, p. 10].

It is important to identify three key areas for positioning cloud-based applications [6]:

+ Infrastructure as a Service (IaaS) - services from cloud providers are produced "on demand". In other words, the clients can build their processes within the framework of available and necessary capacities. This allows them to achieve a high degree of flexibility in the use of resources while creating significant savings for the business.

+ Platform as a service (PaaS). This the sector of the cloud computing offers tools for creating and testing software while having access to the numerous auxiliary tools presented by the provider company (for example, Microsoft Azure).

+ Software as a Service (SaaS) is a type of interaction in which a provider offers access to particular software for many users while ensuring its operability and effective functioning. Instead of installing the essential software on each device of the company, it becomes possible to simultaneously integrate and configure the workflow through online access, or API (Application Programming Interface).

As for the API, it is worth considering separately the aspect that many modern "unicorns", such as PayPal, Uber, and Airbnb, rely heavily on built-in third-party mechanisms that take on many individual functions (e.g., sending SMS, emails or other routine tasks). Entrepreneurs and businesses behind this industry today possess significant market power and actively expand their activities.

$\mathrm{S}$ o, among the API-first companies (primarily creating products that can facilitate the work and development of many aspects of other startups), Stripe can be remarked as one of the leaders. The market capitalization of this company in September 2019, after another round of investment, amounted to $\$ 35$ billion [7]. It should be noted, that such companies as Salesforce and eBay initially developed this sphere as a whole at the beginning of 2000s.

Another example of the successful use of the APIfirst approach as a business model is Checkr. This company provides a solution aimed to ease the process of counterparty verification. Such a digitalized mechanism is already used by more than 10 thousand enterprises around the world and allows them to save significant human and financial resources during the verification of contractors. It also eliminates the need for paper procedures [8].

At the end of 2019, the Amazon Web Services platform (hereinafter AWS) was the leading cloud service provider with a market share of $32 \%$ and a revenue of $\$ 9.8$ billion (for the fourth quarter). Next was the Microsoft Azure service with a share of $17 \%$ and $\$ 5.3$ billion. At the same time, Google Cloud, which took third place, has a market share of only $6 \%$ and $\$ 1.8$ billion in revenue [9].

As for the financial distribution between the private and open cloud models, according to forecasts, by 2025 almost $90 \%$ of the revenue will originate from public cloud storage services, which are represented mainly by the players listed above. However, concerning the competitive conditions in this market, despite clear leaders such as AWS, Microsoft Azure and Google Drive, this sphere, like many other niches in the digital economy, is still open for innovation by small startups and companies. We can notice many relatively small players, such as Alteryx (analysis and data processing), Twilio (communication with customers) and SimilarWeb (site statistics by traffic and various marketing aspects).

They are aimed at solving specific problems that arise everywhere in the digital space, and thus can successfully play "on the field", where large competitors are already present. This may indicate that, in general, the innovation of cloud storage gives a good stimulus to both the development of future market leaders and labor productivity (by saving time on various analog procedures). 
Considering cloud technologies in the context of other areas of digitalization, we can state that there is a significant relationship between most of the directions of the Fourth Industrial Revolution. Therefore, innovations based on cloud computing technologies can be developed in such areas as: "the Internet of things"; artificial intelligence (autonomous decision-making and data processing mechanisms); machine learning (automation of production); Big Data (commercialization of "understanding" large volumes of information); mobile solutions (e. g. Dropbox and Google Drive apps).

A s a practical example, which can also be considered as a demonstration of the capabilities of cloud technologies in comparison with previously widespread practices of creating private infrastructure (including by startups at the stage of the initial product development without sufficient amount of data on possible demand fluctuations), we should consider Niantic. The Pokémon GO game created by the company was launched in the summer of 2016, and in a short time gained immense popularity, exceeding the developers' expectations by the factor of ten. Initially, the margin of safety of the system was planned to be only 5 times greater than the most optimistic forecasts for the number of users.

Even so, the traffic exceeded expectations by more than 50 times. Eventually, the developers managed to carry out the necessary scaling by the use of cloud solutions (and with the help from Google engineers), without the need to put the project on hold and inevitably lose its position in the market [10].

However, on the way of introducing even such global and perspective (and in many areas today real) technology, one can notice many obstacles and contradictions - both from the side of individual users and from corporate clients. For example, even though according to a survey (in which took part 590 IT managers of various companies) from O'Reilly, more than $70 \%$ of organizations in one way or another have experience using cloud technologies in their work, $50 \%$ of respondents note a lack of competencies for the full implementation of transition [11].

Here we can note one more problematic aspect of the entire digital economy today - data storage security and personal privacy. In the wake of criticism towards large corporations (e.g. Facebook) regarding the provision of unreasonable access to user data by third parties and organizations (not to mention massive data leaks), this factor is called important when deciding on implementing cloud technologies by $45 \%$ of the respondents [12]. This trend once again draws attention to the problem of data security in the digital era. According to IBM, the average damage from data leak in the world in 2019 was about $\$ 3.9$ million, which would mean around $\$ 150$ per record [13].

Also, $40 \%$ of respondents noted that their organization used hybrid cloud solutions that combine the func- tions of two main types. According to them, some company information, for one reason or another, cannot be located on public cloud storages [11].

As for the security of the cloud infrastructure (IaaS model), according to the Cloud Strategy Leadership study by Gartner, in the course of 2020 , it will be $60 \%$ less subject to hacker attacks and data leaks than traditional solutions [14, p. 14]. However, individual users (whose total number is exploding as Internet technologies penetrate the life of every active participant in modern society), despite being aware of the risks of losing personal information, sometimes prefer to rely on familiar infrastructure. According to the Boston Consulting Group, one in four using private cloud systems mistakenly believes that their data is stored safely, while public cloud solutions, as noted above, are more secure [15].

In turn, according to a study conducted by Fujitsu, one of the significant factors (62\% of respondents) that slows down the transition of companies to the use of cloud solutions, is the price of such a change [16]. There is also a lack of awareness of the long-term benefits and significant savings when implementing public cloud solutions.

A lso, we should not forget about the emerging relationship between the cloud service provider and the client, relying on infrastructure and software. If operations become discontinued by the cloud service provider, then the client may become "stuck" inside this system and incur significant losses. According to Eurostat, as of 2018, among European Union enterprises that use public cloud systems in their work, $55 \%$ were categorized as highly dependent on them (which means using such tools in accounting, customer relations and/or to maintain the functioning of important software) [17].

On the way to overcoming these, and many other closely interconnected obstacles to setting up ever new broad technologies of the digital revolution in economic processes, we should not underestimate the role of government initiatives. We can say that sometimes it is the institutional efforts and projects for implementing modern tools that can contribute to their further dissemination and implementation. The active participation of the state as a leading user of a particular technology may even lead to the creation of a market where there will be a significant demand for a certain innovation [18, p. 60].

As an effective measure to stimulate the creation and implementation of cloud innovations (including those in the public sector), we should mention the socalled "cloud first" approach. Within the framework of this policy, many initiatives are expected to be implemented at the state level. The USA is considered the world leader in this trend, where such measures were taken back in 2011 [19].

As for the experience of the European Union, the "European Cloud Computing Strategy", first formed by the European Commission in 2012, also outlined many 
challenges arising from the introduction of such innovations. Here it is worth noting several aspects that are important to ensure an effective supply in the cloud technology market: security (mandatory compliance with European Commission data protection standards); hybridity (the ability to implement both open and private solutions, depending on specific goals and projects); "multicloud" (which means the presence of healthy competition and the ability to choose between several offerings); energy efficiency (general norms and rules of the EU to reduce carbon dioxide emissions into the atmosphere) [20].

\section{CONCLUSIONS}

This paper contains a comprehensive analysis of the main aspects concerning the role and prospects of cloud solutions in the context of the digitalization process. Were considered the comprehensive examples of the successful use of cloud mechanisms in creating digital products and the process of scaling their market presence. The characteristics of the largest areas of cloud innovations (IaaS, SaaS, PaaS), as well as obstacles to their broader implementation in economic activity, were given to explain the complex structure of the digital and digitalized economy.

Based on the study, we can state the need for a comprehensive institutional policy to stimulate the introduction of digital technologies and cloud solutions in particular. Based on the examples presented in the article, we can see that in the conditions of a particularly dynamically changing modern digital economy, this approach can become a significant factor in increasing competitiveness and efficiency at both the macro- and micro-level.

Further scientific and practical research, justification of the feasibility of using cloud technology in the economy, is a relevant topic requiring both active institutional and entrepreneurial participation.

As a result of the research, we can note the presence of hidden barriers to introducing cloud computing technologies for use by companies from various industries. In further studies of this aspect, it is necessary to pay close attention to the problem of forming an effective broad institutional policy to stimulate innovation at the state level. A study by O'Reilly confirms this need, pointing to a general lack of competencies in implementing cloud technologies in commercial processes. The results of this study can help a wide range of participants in the modern digital economy to approach the choice of new technologies more reasonably, based on the global picture of macro shifts in the conditions of the Fourth Industrial Revolution and the prospects for its further expansion.

\section{LITERATURE}

1. Digital Economy Compass 2019. Statista. URL: https:// cdn.statcdn.com/download/pdf/DigitalEconomyCompass2019.pdf
2. The importance of data analysis in autonomous vehicle development / DXC Technology Company. URL: https://www.dxc.technology/auto/insights/146742the_importance_of_data_analysis_in_autonomous_ vehicle_development

3. Reinsel D., Gantz J., Rydning J. The Digitization of the World. From Edge to Core. URL: https://www.seagate. com/files/www-content/our-story/trends/files/idcseagate-dataage-whitepaper.pdf

4. Governments Embracing Cloud. An Opportunity for Modernization, Innovation and Transformation / Information Technology Association of Canada. URL: https://itac.ca/wp-content/uploads/2019/09/ITACgovt-Cloud-paper-Eng-aug2019-final.pdf

5. Half-Yearly Review Shows $\$ 150$ billion Spent on Cloud Services and Infrastructure / Synergy Research Group. URL: https://www.srgresearch.com/articles/half-yearly-review-shows-150-billion-spent-cloud-servicesand-infrastructure

6. Jones E. Cloud Market Share - a Look at the Cloud Ecosystem in 2020. URL: https://kinsta.com/blog/cloudmarket-share/

7. Fuscaldo D. Stripe Now Has a Valuation of $\$ 35$ Billion. URL: https://www.forbes.com/sites/donnafuscaldo/2019/09/19/stripe-now-has-a-pre-money-valuation-of-35-billion/\#40d65e1562e6

8. Levine D. APIs are the next big SaaS wave. URL: https:// techcrunch.com/2019/09/06/apis-are-the-next-bigsaas-wave/

9. Stalcup K. AWS vs Azure vs Google Cloud Market Share 2020: What the Latest Data Shows. URL: https://www. parkmycloud.com/blog/aws-vs-azure-vs-googlecloud-market-share/

10. Hoff T. Case Study: Pokémon GO On Google Cloud Load Balancing. URL: http://highscalability.com/ blog/2018/8/8/case-study-pokemon-go-on-googlecloud-load-balancing.html

11. Whitney L. Moving to the cloud: Top challenges organizations face. URL: https://www.techrepublic.com/article/organizations-face-multiple-challenges-tryingto-adopt-cloud-technology/

12. Wong J. The Cambridge Analytica scandal changed the world - but it didn't change Facebook. URL: https://www.theguardian.com/technology/2019/ mar/17/the-cambridge-analytica-scandal-changedthe-world-but-it-didnt-change-facebook

13. Cost of a Data Breach Report 2019 / Ponemon Institute. URL: https://www.all-about-security.de/filead$\mathrm{min} /$ micropages/Fachartikel_28/2019_Cost_of_a_ Data_Breach_Report_final.pdf

14. Smith D. Cloud Strategy Leadership. Gartner Insights on How and Why Leaders Must Implement Cloud Computing. URL: https://www.gartner.com/imagesrv/ books/cloud/cloud_strategy_leadership.pdf

15. Gupta A., Kushansh K., Santhanam P. et al. Ascent to the Cloud. How Six Key APAC Economies Can Lift-Off. URL: http://image-src.bcg.com/Images/Ascent_to_ the_Cloud_Report_210ct_tcm9-231826.pdf

16. UK Public Sector: Why the Journey to the Cloud is like Pizza. Survey Report 2019 / iGov Survey. URL: https:// www.fujitsu.com/uk/imagesgig5/Public-Sector-Research.pdf 
17. Cloud computing - statistics on the use by enterprises / Eurostat. URL: https://ec.europa.eu/eurostat/statisticsexplained/index.php?title=Cloud_computing_-_statistics_on_the_use_by_enterprises\#Enterprises. E2.80.99_dependence_on_cloud_computing

18. Stimulating digital innovation for growth and inclusiveness. The role of policies for the successful diffusion of ICT // OECD Digital Economy Papers. URL: https:// www.oecd-ilibrary.org/docserver/5jlwqvhg3|31-en. pdf?expires $=1581784334 \& i d=i d \& a c c n a m e=$ guest $\& \mathrm{ch}$ ecksum=08AD107A4420640333D5277BA3D9300D

19. A Cloud Timeline: U. S. Government's Modernization Journey / Amazon Web Services. URL: https://aws. amazon.com/ru/blogs/publicsector/a-cloud-timelineu-s-governments-modernization-journey/

20. European Commission Cloud Strategy - Cloud as an enabler for the European Commission Digital Strategy / European Commission. 16 May 2019. v.1.01. URL: https://ec.europa.eu/info/sites/info/files/ec_cloud_ strategy.pdf

\section{REFERENCES}

"A Cloud Timeline: U. S. Government's Modernization Journey". Amazon Web Services. https://aws.amazon.com/ ru/blogs/publicsector/a-cloud-timeline-u-s-governments-modernization-journey/

"Cloud computing - statistics on the use by enterprises". Eurostat. https://ec.europa.eu/eurostat/statisticsexplained/index.php?title=Cloud_computing_-_statistics_on_the_use_by_enterprises\#Enterprises. E2.80.99_dependence_on_cloud_computing

"Cost of a Data Breach Report 2019". Ponemon Institute. https://www.all-about-security.de/fileadmin/micropages/Fachartikel_28/2019_Cost_of_a_Data_Breach_ Report_final.pdf

"Digital Economy Compass 2019. Statista". https://cdn. statcdn.com/download/pdf/DigitalEconomyCompass2019.pdf

"European Commission Cloud Strategy - Cloud as an enabler for the European Commission Digital Strategy". European Commission. 16 May 2019. https://ec.europa. eu/info/sites/info/files/ec_cloud_strategy.pdf

Fuscaldo, D. "Stripe Now Has a Valuation of $\$ 35$ Billion". https://www.forbes.com/sites/donnafuscaldo/2019/09/19/stripe-now-has-a-pre-money-valuation-of-35-billion/\#40d65e1562e6

"Governments Embracing Cloud. An Opportunity for Modernization, Innovation and Transformation". Information Technology Association of Canada. https://itac. ca/wp-content/uploads/2019/09/ITAC-govt-Cloudpaper-Eng-aug2019-final.pdf

Gupta, A. et al. "Ascent to the Cloud. How Six Key APAC Economies Can Lift-Off". http://image-src.bcg.com/
Images/Ascent_to_the_Cloud_Report_210ct_tcm9231826.pdf

"Half-Yearly Review Shows $\$ 150$ billion Spent on Cloud Services and Infrastructure". Synergy Research Group. https://www.srgresearch.com/articles/half-yearlyreview-shows-150-billion-spent-cloud-services-andinfrastructure

Hoff, T. "Case Study: Pokemon GO On Google Cloud Load Balancing". http://highscalability.com/blog/2018/8/8/ case-study-pokemon-go-on-google-cloud-load-balancing.html

Jones, E. "Cloud Market Share - a Look at the Cloud Ecosystem in 2020". https://kinsta.com/blog/cloud-marketshare/

Levine, D. "APIs are the next big SaaS wave". https://techcrunch.com/2019/09/06/apis-are-the-next-big-saaswave/

Reinsel, D., Gantz, J., and Rydning, J. "The Digitization of the World. From Edge to Core". https://www.seagate. com/files/www-content/our-story/trends/files/idcseagate-dataage-whitepaper.pdf

"Stimulating digital innovation for growth and inclusiveness. The role of policies for the successful diffusion of ICT". OECD Digital Economy Papers. https://www. oecd-ilibrary.org/docserver/5jlwqvhg3|31-en.pdf?exp ires $=1581784334 \& i d=i d \& a c c n a m e=$ guest $\&$ checksum =08AD107A4420640333D5277BA3D9300D

Smith, D. "Cloud Strategy Leadership. Gartner Insights on How and Why Leaders Must Implement Cloud Computing". https://www.gartner.com/imagesrv/books/ cloud/cloud_strategy_leadership.pdf

Stalcup, K. "AWS vs Azure vs Google Cloud Market Share 2020: What the Latest Data Shows". https://www.parkmycloud.com/blog/aws-vs-azure-vs-google-cloudmarket-share/

"The importance of data analysis in autonomous vehicle development". DXC Technology Company. https:// www.dxc.technology/auto/insights/146742-the_importance_of_data_analysis_in_autonomous_vehicle_ development

"UK Public Sector: Why the Journey to the Cloud is like Pizza. Survey Report 2019“. iGov Survey. https://www.fujitsu.com/uk/imagesgig5/Public-Sector-Research.pdf

Whitney, L. "Moving to the cloud: Top challenges organizations face". https://www.techrepublic.com/article/ organizations-face-multiple-challenges-trying-toadopt-cloud-technology/

Wong, J. "The Cambridge Analytica scandal changed the world - but it didn't change Facebook". https://www. theguardian.com/technology/2019/mar/17/the-cambridge-analytica-scandal-changed-the-world-but-itdidnt-change-facebook 